\title{
Changes in Plasma Concentrations and mRNA Expression of Hepatokines Fetuin A, Fetuin B and FGF21 in Physiological Pregnancy and Gestational Diabetes Mellitus
}

\author{
P. ŠIMJÁK ${ }^{1}$, A. CINKAJZLOVÁ ${ }^{2,3}$, K. ANDERLOVÁ ${ }^{1,4}$, J. KLOUČKOVÁ ${ }^{2,3,5}$, \\ H. KRATOCHVÍLOVÁ ${ }^{2,3,5}$, Z. LACINOVÁ ${ }^{2,3}$, P. KAVÁLKOVÁ ${ }^{3}$, H. KREJČÍ ${ }^{1,4}$, \\ M. MRÁZ ${ }^{3,6}$, A. PAŘÍZEK ${ }^{1}$, M. KRŠEK ${ }^{4,7}$, M. HALUZÍK ${ }^{2,3,5,6}$
}

${ }^{1}$ Gynecology and Obstetrics Department, First Faculty of Medicine, Charles University and General University Hospital, Prague, Czech Republic, ${ }^{2}$ Center for Experimental Medicine, Institute for Clinical and Experimental Medicine, Prague, Czech Republic, ${ }^{3}$ Institute of Medical Biochemistry and Laboratory Diagnostics, First Faculty of Medicine, Charles University and General University Hospital, Prague, Czech Republic, ${ }^{4}$ Third Department of Medicine, First Faculty of Medicine, Charles University and General University Hospital, Prague, Czech Republic, ${ }^{5}$ Institute of Endocrinology, Prague, Czech Republic, ${ }^{6}$ Diabetes Center, Institute for Clinical and Experimental Medicine, Prague, Czech Republic, ${ }^{7}$ Second Department of Internal Medicine, Third Faculty of Medicine, Charles University and University Hospital Královské Vinohrady, Prague, Czech Republic

Received August 13, 2018

Accepted September 3, 2018

\section{Summary}

We measured plasma concentrations, adipose tissue and placental mRNA expression of hepatokines fetuin A, fetuin B and fibroblast growth factor 21 (FGF21) in 12 healthy pregnant women ( $\mathrm{P}$ group), 12 pregnant women with gestational diabetes (GDM) and 10 healthy non-pregnant women ( $\mathrm{N}$ group) to explore their potential role in the etiopathogenesis of GDM. GDM and P group had comparable BMI, C-reactive protein (CRP) and glycated hemoglobin levels while IL-10 and TNF-a levels were higher in GDM group. Fetuin A and fetuin B levels were higher in pregnancy as compared to $\mathrm{N}$ group and decreased after delivery with no apparent influence of GDM. In contrast, the pattern of changes of circulating FGF21 levels differed between GDM and $P$ group. Fetuin A concentrations positively correlated with CRP, TNF-a mRNA expression in adipose tissue and IL-6 mRNA expression in placenta. Fetuin $B$ positively correlated with CRP. FGF21 levels correlated positively with IFN- $\gamma$ mRNA in adipose tissue and inversely with IL- 8 mRNA in the placenta. Taken together, fetuin $A$ and fetuin $B$ levels were increased during pregnancy regardless of the presence of GDM. In contrast, FGF21 patterns differed between healthy pregnant women and GDM patients suggesting a possible role of this hepatokine in the etiopathogenesis of GDM.

\section{Key words}

Fetuin A • Fetuin B • FGF21 • Pregnancy • Gestational diabetes mellitus

\section{Corresponding author}

M. Haluzík, Institute for Clinical and Experimental Medicine, Vídeňská 1958/9, Prague 4, 14021, Czech Republic. E-mail: halm@ikem.cz

\section{Introduction}

Gestational diabetes mellitus shares common features with type 2 diabetes mellitus (T2DM) and its history represents a major risk factor for the development of T2DM later in life (Elnour et al. 2008, Seshiah et al. 2006, Vejrazkova et al. 2017). Liver plays a central role in glucose metabolism as not only a major place of gluconeogenesis and glycogen storage but also as a source of numerous hormones commonly referred to as hepatokines (Abdul-Wahed et al. 2014, Spolcova et al. 2014). These hormones including fetuin A, fetuin B and fibroblast growth factor 21 (FGF21) have all been connected with regulation of glucose metabolism and 
energy homeostasis.

Fetuin $\mathrm{A}$ and fetuin $\mathrm{B}$ are both members of cystatine fetuin family. Fetuin A, also referred to as a2-Heremans-Schmid glycoprotein, is secreted by liver and adipose tissue (Jialal et al. 2015). It acts as a natural inhibitor of the insulin receptor tyrosine kinase (Srinivas et al. 1993) and possibly as an endogenous ligand of tolllike receptor 4 ( $\mathrm{Pal}$ et al. 2012). Fetuin A is associated with insulin resistance, fat accumulation in the liver (Stefan et al. 2006), T2DM (Stefan et al. 2008, Sun et al. 2013), metabolic syndrome and atherogenic lipid profile (Ix et al. 2006). It also contributes to macrophage migration to the adipose tissue and proinflammatory macrophage phenotype (Chatterjee et al. 2013) along with repression of adiponectin mRNA expression and induction of pro-inflammatory TNF- $\alpha$, IL-1 $\beta$ cytokine expression (Hennige et al. 2008). Another member of cystatine fetuin family - fetuin B is produced by the liver, tongue and placenta (Denecke et al. 2003). In experimental studies in mice, fetuin B impaired insulin signaling in the muscle and the liver and reducing fetuin $B$ improves glucose tolerance in obese mice. In humans, fetuin B was increased in obese patients with liver steatosis as compared to obese subjects without steatosis and positively correlated with fasting insulin and HOMA-IR (Meex et al. 2015).

FGF21 is a member of the FGF superfamily produced predominantly by the liver and adipose tissue (Fon Tacer et al. 2010). In mice, FGF21 stimulated glucose uptake in adipocytes and showed lipid-lowering, thermogenic and insulin-sensitizing effects (Badman et al. 2007, Kharitonenkov et al. 2005, Telejko et al. 2009). FGF21 exerts its biological action after binding to high-affinity FGF receptors belonging to the tyrosine kinase receptor family. Co-factor $\beta$ Klotho, a homologous single-pass transmembrane protein that binds to specific FGFRs, was identified as an essential prerequisite for FGF21 activity (Ogawa et al. 2007). Increased FGF21 levels were observed in patients with obesity and T2DM (Dostalova et al. 2009, Mumtaz et al. 2015). Bariatric surgery decreased FGF21 levels (Haluzikova et al. 2013) while short-term very low calorie diet had an opposite effect (Mraz et al. 2009).

The possible significance of changes in fetuin A, fetuin B and FGF21 in patients with gestational diabetes mellitus and its relationship to its clinical features is not fully clarified. We hypothesized that systemic levels or fat and placenta mRNA expression of these hepatokines will differ between healthy pregnant women and patients with GDM and that these differences could contribute to metabolic disturbances in GDM patients. To this end, we explored the changes in circulating fetuin A, fetuin B and FGF21 levels and their mRNA expression in placenta and adipose tissue in pregnant women with and without GDM and healthy non-pregnant women and explored its relationship to clinical features and measures of glucose metabolism and subclinical inflammation.

\section{Methods}

\section{Study subjects}

The study was performed at a single tertiary level department of obstetrics and gynecology. Studied pregnant subjects included 12 healthy women and 12 pregnant women with GDM. GDM was diagnosed via $75 \mathrm{~g}, 2$-h oral glucose tolerance test using IADPSG criteria. Exclusion criteria were multiple pregnancy, chronic systemic disease or other pregnancy-related conditions. Ten non-pregnant women who underwent diagnostic laparoscopy for common gynecological indications were included in the study.

Women diagnosed with GDM received dietary counseling and underwent diabetologic surveillance. In one case insulin treatment had to be initiated at 33 weeks and in two cases oral glucose-lowering medication (metformin) was administered at 30 and 31 weeks of gestation to ensure appropriate glucose control.

Each subject signed written informed consent and the Human Ethics Committee, First Faculty of Medicine and General University Hospital, Prague, Czech Republic, approved the studies. The study was performed in accordance with the principles of the Declaration of Helsinki as revised in 2008.

\section{Blood and adipose tissue sampling}

Clinical examination was performed and blood samples were taken at 28 to 32 weeks of gestation (visit 1), 36 to 38 weeks of gestation (visit 2) and 6 to 12 months after delivery (visit 3 ). In the group of non-pregnant women, a single clinical examination and blood drawing were performed before the laparoscopic operation.

Blood samples were taken after an overnight fasting and centrifuged for $10 \mathrm{~min}$ at $3,000 \mathrm{xg}$ within $30 \mathrm{~min}$ after withdrawal. Serum or plasma aliquots were subsequently stored at $-80{ }^{\circ} \mathrm{C}$.

Samples of mixed cord blood were taken after delivery of the fetus and delayed umbilical cord clamping in all pregnant women. Within $30 \mathrm{~min}$, the blood was centrifuged for $10 \mathrm{~min}$ at $3,000 \mathrm{x}$ g. Serum or plasma 
aliquots were then stored at $-80{ }^{\circ} \mathrm{C}$.

In case of operative delivery, the adipose tissue biopsy was taken from the episiotomy or visceral and subcutaneous adipose tissue if the cesarean section had to be performed. Samples of perineal adipose tissue were obtained from 5 women without GDM and 5 women with GDM. Visceral and subcutaneous adipose tissue was obtained from 6 women without GDM and 6 women with GDM. Placental tissue was obtained from all women regardless of the mode of delivery. Adipose tissue samples were immediately placed in the RNAlater ${ }^{\circledR}$ solution (Ambion ${ }^{\circledR}$ - Invitrogen, Carlsbad, California, USA) and were stored at $-80^{\circ} \mathrm{C}$.

\section{Hormonal and biochemical assays}

Plasma fetuin A levels were measured by ELISA kit (Biovendor, Brno, Czech Republic) with sensitivity $0.104 \mathrm{ng} / \mathrm{ml}$. Plasma fetuin B levels were measured by ELISA kit (Biovendor, Brno, Czech Republic). Sensitivity was $0.19 \mathrm{ng} / \mathrm{ml}$. Plasma FGF21 levels were measured by ELISA kit (Biovendor, Brno, Czech Republic). Sensitivity was $7 \mathrm{ng} / \mathrm{ml}$. C-reactive protein (CRP) levels were measured by instant ELISA kit (eBioscience, Vienna, Austria) with sensitivity $3 \mathrm{pg} / \mathrm{ml}$. The intra- and interassay variabilities for all assays were between 5.0 and $10.0 \%$.

Serum levels of cytokines were measured by multiplex assay MILLIPLEX MAP Human High Sensitivity $T$ Cell Panel (Merck KGaA, Darmstadt, Germany). Sensitivity for IFN- $\gamma$ was $0.48 \mathrm{pg} / \mathrm{ml}, \mathrm{IL}-10$ was $0.56 \mathrm{pg} / \mathrm{ml}$, IL-6 was $0.11 \mathrm{pg} / \mathrm{ml}$, IL- 8 was $0.13 \mathrm{pg} / \mathrm{ml}$ and for TNF- $\alpha$ was $0.16 \mathrm{pg} / \mathrm{ml}$. The intra- and interassay variabilities for all assays were between 5.0 and $15.0 \%$.

Biochemical parameters (urea, creatinine, uric acid, total bilirubin, ALT, AST, ALP, GGT, glycated hemoglobin $-\mathrm{HbA}_{1 \mathrm{c}}$, HDL cholesterol, total cholesterol, triglycerides) were measured and LDL cholesterol was calculated at the Department of Biochemistry, General University Hospital, Prague, Czech Republic by standard laboratory methods.

\section{Quantitative real time $P C R$}

Samples of adipose tissue were homogenized on MagNA Lyser Instrument (Roche Diagnostics GmbH, Mannheim, Germany). Total RNA was extracted on MagNA Pure instrument using Magna Pure Compact RNA Isolation kit (tissue) (Roche Diagnostics $\mathrm{GmbH}$, Mannheim, Germany). RNA concentration was determined from absorbance at $260 \mathrm{~nm}$ on NanoPhotometer (Implen,
Munchen, Germany). Reverse transcription was performed using random primers according to the manufacturer's protocol of the High-Capacity cDNA Reverse Transcription Kits (Applied Biosystems, Foster City, CA, USA). Input amount of RNA was $250 \mu \mathrm{g}$ per reaction. Gene expression was performed on a 7500 Real-Time PCR System (Applied Biosystems, Foster City, CA, USA). For reaction, a mix of TaqMan ${ }^{\circledR}$ Universal PCR Master Mix II, NO AmpErase ${ }^{\circledR}$ UNG (Applied Biosystems, Foster City, CA, USA), nuclease-free water (Fermentas Life Science, Vilnius, Lithuania) and specific TaqMan ${ }^{\circledR}$ Gene Expression Assays (fetuin A: Hs00155659_m1, fetuin B: Hs00608480_m1, IFN- $\gamma$ : Hs00174143_m1, IL-6: Hs00174131_m1, IL-8: Hs00174103_m1, TNF- $\alpha$ : Hs00174128_m1, leptin: Hs00174877_m1, beta-2 microglobulin (B2M): Hs 99999907_m1, all Applied Biosystems, Foster City, CA, USA) were used. B2M was applied as endogenous reference. The formula $2^{- \text {ddCt }}$ was used to calculate relative gene expression.

\section{Statistical analysis}

Statistical analysis was performed and graphs were drawn using SigmaPlot 13.0 (SPSS Inc., Chicago, IL, USA). Results are expressed as means \pm standard error of the mean (SEM). One way ANOVA/One way RM ANOVA followed by Holm-Sidak test, One way ANOVA on Ranks/One way RM ANOVA on Ranks followed by Dunn's method, unpaired t-test or Mann-Whitney Rank Sum Test, paired-test or Wilcoxon Signed-Rank were used for the assessment of intergroup differences, as appropriate. Spearman or Pearson correlation test was used to assess the association between fetuin A, fetuin B or FGF21 and other measured parameters. The baseline results of non-pregnant and all pregnant women (V1) were used for correlation analyses. Statistical significance was assigned to $\mathrm{p}<0.05$.

\section{Results}

The effect of pregnancy and gestational diabetes mellitus on biochemical parameters

The age of women in all three groups was comparable. The BMI of the non-pregnant women $\left(22.6 \pm 0.98 \mathrm{~kg} / \mathrm{m}^{2}\right)$ and pre-pregnancy BMI of women with $\left(23.8 \pm 1.39 \mathrm{~kg} / \mathrm{m}^{2}\right)$ and without gestational diabetes $\left(22.9 \pm 1.09 \mathrm{~kg} / \mathrm{m}^{2}\right)$ did not differ $(\mathrm{p}=0.865)$ similarly to BMI between the two groups of pregnant patients during the study visits (Table 1). 


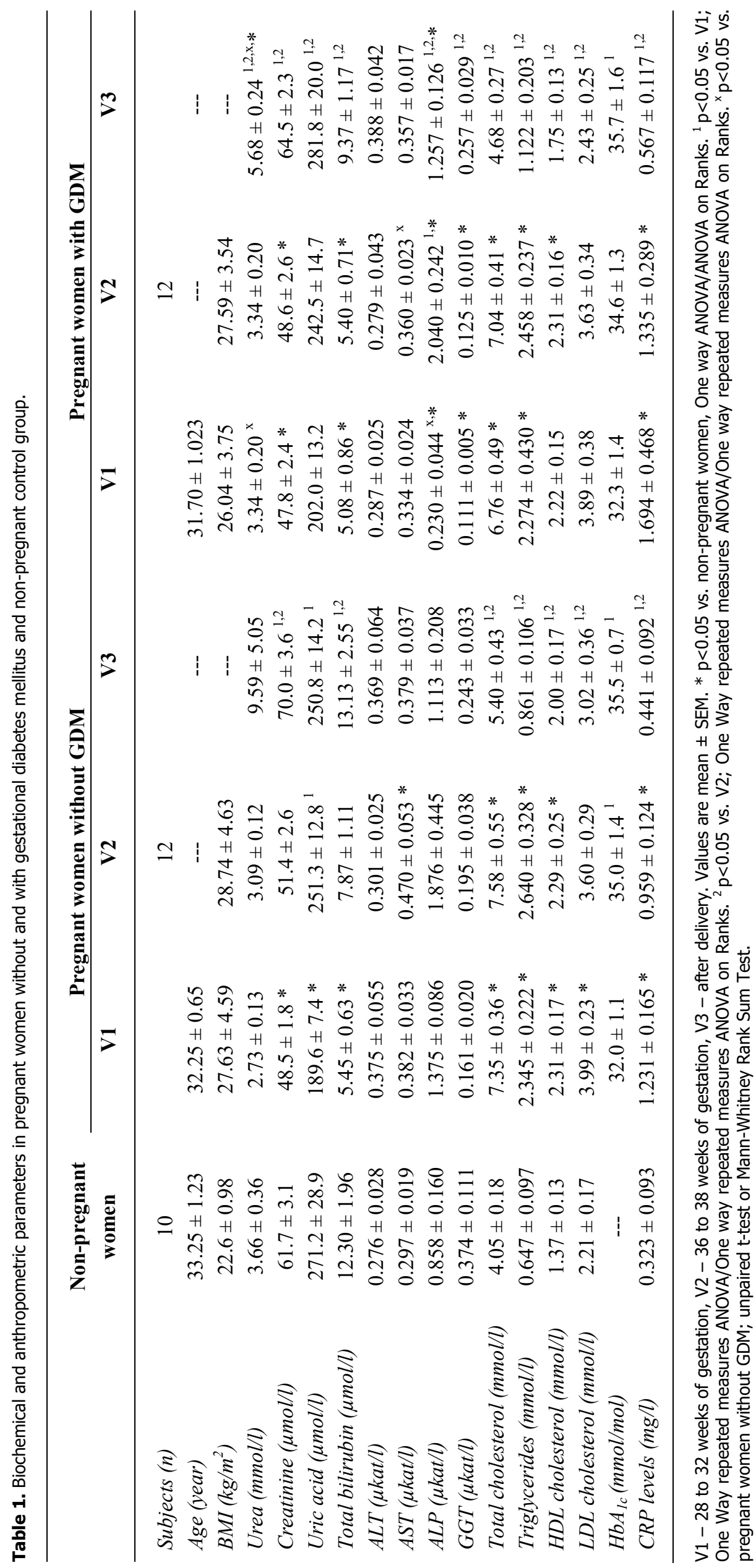


Differences in line with physiological changes in pregnancy including lower levels of creatinine, uric acid and total bilirubin and higher levels of total cholesterol, triglycerides, HDL cholesterol and LDL cholesterol were found between the non-pregnant control group and both groups of pregnant women at V1. Pregnant women with GDM had increased urea and decreased ALP levels compared to pregnant women without GDM while no difference was observed in $\mathrm{HbA}_{1 \mathrm{c}}$ (Table 1).

All studied biochemical characteristics of the subjects in V2 followed the course observed in V1. At 6 to 12 months after delivery (V3), no difference was observed between non-pregnant women and women without GDM. At the same visit, pregnant women with GDM had higher urea and ALP compared to nonpregnant women (Table 1).

CRP levels were increased during pregnancy in both pregnant women with and without GDM compared to healthy control subjects with no significant differences between GDM and healthy pregnant women. After pregnancy, CRP levels decreased to levels comparable to healthy control subjects.

The effect of pregnancy and gestational diabetes mellitus on circulating and cord blood concentrations of fetuin A, fetuin B and FGF21

Pregnant women without GDM had higher fetuin A levels during the whole study period (V1 and V2) compared to non-pregnant group although their fetuin A levels decreased significantly after delivery. Compared to non-pregnant women, GDM group showed similar pattern with higher fetuin A levels at V1 while V2 and V3 values did not significantly differ from non-pregnant group. No significant differences in fetuin A concentrations between healthy pregnant and GDM group were detected. Cord blood fetuin A levels were higher in pregnant women without GDM compared to GDM group (Fig. 1).

Fetuin A: the effect of pregnancy and cord blood levels
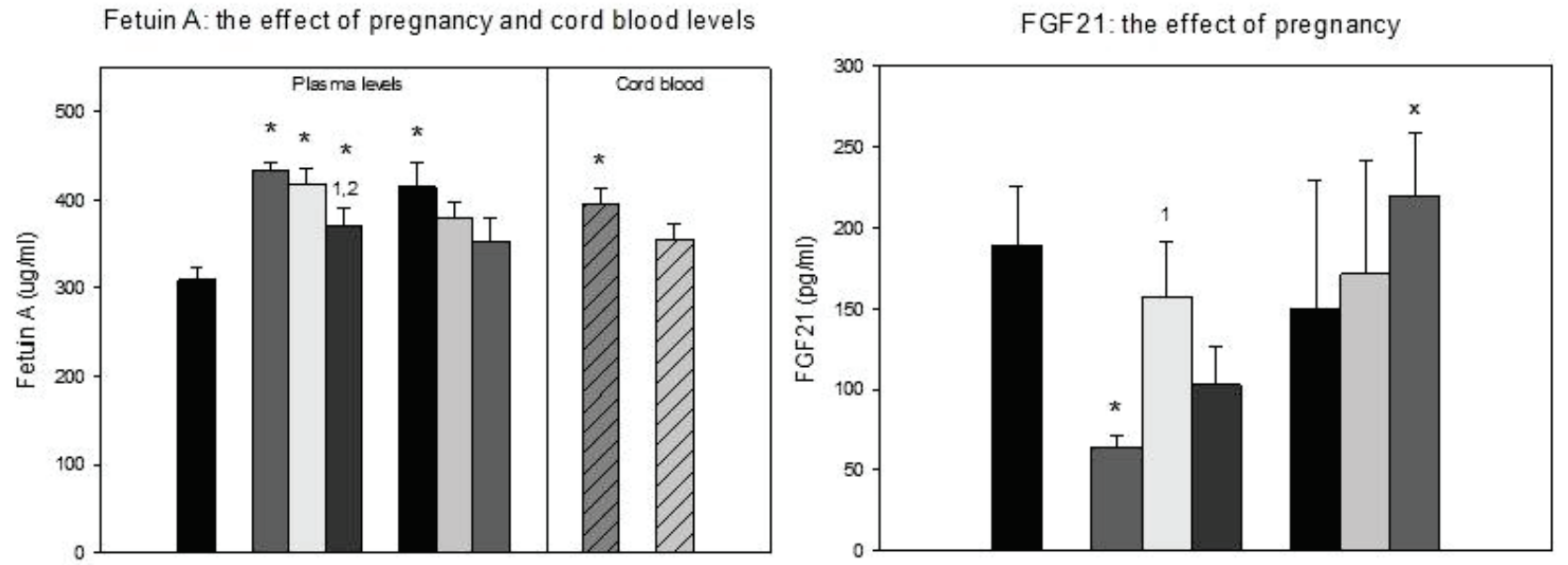

Fetuin B: the effect of pregnancy and cord blood levels
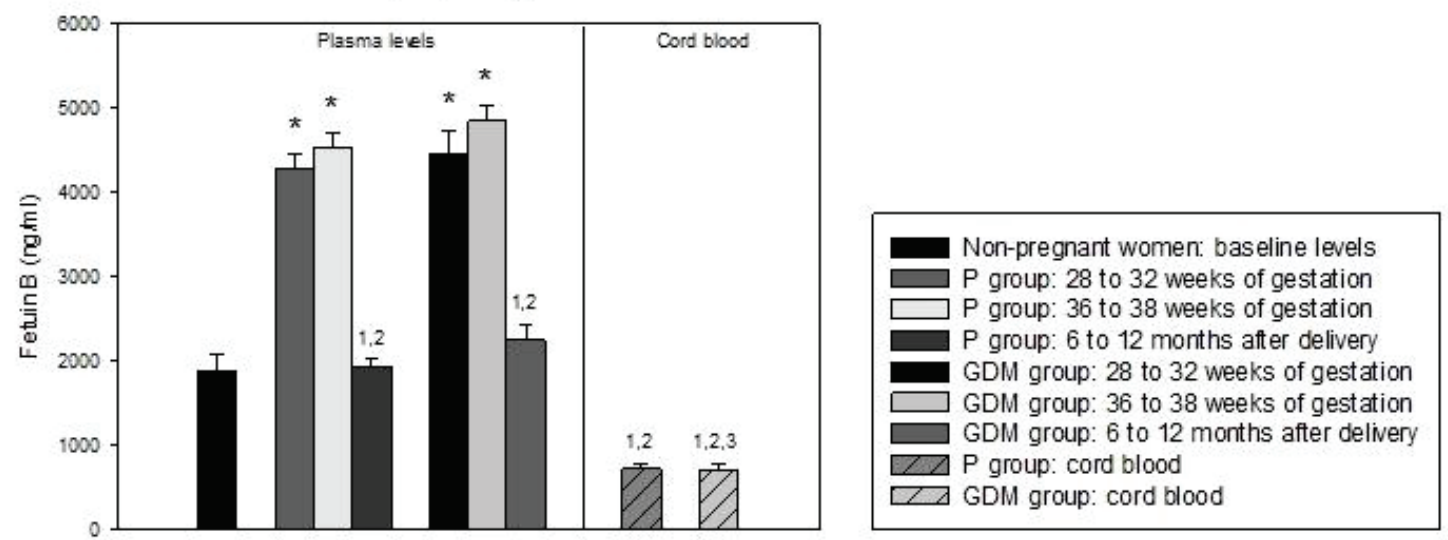

Fig. 1. The effect of pregnancy and GDM on fetuin A, fetuin B and FGF21 levels. FGF21 levels were not determined in cord blood. $\mathrm{N}$ - non-pregnant women, $\mathrm{P}$ - pregnant women without GDM, GDM - pregnant women with GDM. Values are mean $\pm \mathrm{SEM}$. $* \mathrm{p}<0.05$ vs. non-pregnant women, One way ANOVA/ANOVA on Ranks. ${ }^{1} \mathrm{p}<0.05$ vs. V1; One way repeated measures ANOVA/One way repeated measures ANOVA on Ranks. ${ }^{2} \mathrm{p}<0.05$ vs. V2; One way repeated measures ANOVA/One way repeated measures ANOVA on Ranks. ${ }^{3} p<0.05$ vs. V3; One way ANOVA/One way ANOVA on Ranks. ${ }^{x} p<0.05$ vs. pregnant women without GDM; unpaired t-test or Mann-Whitney Rank Sum Test. 
Both groups of pregnant women had higher fetuin B levels at V1 and V2 compared to non-pregnant women. After delivery (V3), fetuin B levels decreased to concentrations comparable with those of non-pregnant group in both pregnant groups. No differences between healthy pregnant and GDM group were found in plasma or cord blood fetuin B levels (Fig. 1).

Compared to non-pregnant group, healthy pregnant women had lower FGF21 levels at V1 and GDM patients had higher FGF21 after delivery.

The effect of pregnancy and gestational diabetes mellitus on mRNA expression of fetuin A, fetuin B and FGF21 in adipose tissue and placenta

Fetuin A and FGF21 mRNA expression in perineal adipose tissue were under the detection limit, while a weak fetuin B mRNA expression on the borderline of detection limit of the method in perineal adipose tissue was noted and did not differ between women without and with GDM. Fetuin B mRNA expression was not detected in the placenta. FGF21 mRNA expression was detected in half of the samples, while fetuin A mRNA expression was detected in placenta, but did not differ between pregnant women with and without GDM. Furthermore, we aimed to assess a difference between mRNA expression of fetuin $\mathrm{A}$ and fetuin B in subcutaneous and visceral adipose tissue. We failed to detect fetuin A mRNA expression in both depots and only weak fetuin B mRNA expression was found in half samples of subcutaneous adipose tissue (data not shown).

The effect of pregnancy and gestational diabetes mellitus on inflammatory cytokines

In healthy pregnant women, the circulating levels of IL-6 at V1 were lower as compared to V2 and V3, respectively (Table 2). No such pattern was found in GDM group. Circulating IL-10 levels in healthy pregnant women significantly increased at V3 as compared to V1 and V2. IL-10 levels at V1 in GDM group were higher than in healthy pregnant women and were not changed at V2 or V3, respectively. During the entire study, TNF- $\alpha$ levels were consistently higher in GDM pregnant women compared to healthy pregnant women.

Perineal adipose tissue IL- 8 mRNA expression was higher in women without GDM (Fig. 2), while mRNA expression of TNF- $\alpha$, IFN- $\gamma$, IL- 6 and leptin did not differ between groups (data not shown). Placental leptin mRNA expression was higher in healthy pregnant women compared to GDM group (Fig. 2). Placental mRNA expression of TNF- $\alpha$, IFN- $\gamma$, IL-6 and IL- 8 did not differ between groups (data not shown).

Table 2. Changes in inflammatory cytokines in pregnant women without and with gestational diabetes mellitus and non-pregnant control group.

\begin{tabular}{|c|c|c|c|c|c|}
\hline & $\begin{array}{c}\text { IFN- } \gamma \\
(\mathrm{pg} / \mathrm{ml})\end{array}$ & $\begin{array}{c}\text { IL-6 } \\
\text { (pg/ml) }\end{array}$ & $\begin{array}{c}\text { IL-8 } \\
(\mathrm{pg} / \mathrm{ml})\end{array}$ & $\begin{array}{c}\text { IL-10 } \\
\text { (pg/ml) }\end{array}$ & $\begin{array}{c}\text { TNF- } \alpha \\
(\mathrm{pg} / \mathrm{ml})\end{array}$ \\
\hline Non-pregnant women & $27.36 \pm 2.76$ & $6.45 \pm 1.54$ & $9.24 \pm 2.18$ & $32.97 \pm 6.62$ & $9.16 \pm 1.44$ \\
\hline \multicolumn{6}{|c|}{ Pregnant women without GDM } \\
\hline$V 1$ & $16.55 \pm 2.30$ & $2.78 \pm 0.37$ & $4.94 \pm 0.52$ & $9.29 \pm 1.79 *$ & $3.88 \pm 0.52 *$ \\
\hline$V 2$ & $19.27 \pm 2.94$ & $3.69 \pm 0.29^{1}$ & $5.84 \pm 0.62$ & $10.25 \pm 1.71 *$ & $5.18 \pm 0.99 *$ \\
\hline$V 3$ & $19.41 \pm 3.34$ & $3.75 \pm 0.49^{1}$ & $5.91 \pm 0.36$ & $16.71 \pm 3.36^{1,2}$ & $5.12 \pm 0.90 *$ \\
\hline Cord blood & --- & $3.75 \pm 1.31$ & $13.07 \pm 4.19^{1}$ & --- & $6.37 \pm 0.88$ \\
\hline \multicolumn{6}{|c|}{ Pregnant women with GDM } \\
\hline$V 1$ & $19.18 \pm 3.31$ & $4.33 \pm 0.81$ & $5.78 \pm 0.53$ & $20.88 \pm 3.86^{\mathrm{x}}$ & $10.99 \pm 1.81^{\mathrm{x}}$ \\
\hline$V 2$ & $20.58 \pm 4.17$ & $5.02 \pm 1.13$ & $6.31 \pm 0.75$ & $17.93 \pm 4.65$ & $12.16 \pm 1.74^{\mathrm{x}}$ \\
\hline$V 3$ & $24.46 \pm 5.98$ & $5.93 \pm 1.81$ & $7.79 \pm 0.83$ & $17.34 \pm 4.48$ & $12.13 \pm 2.10^{\mathrm{x}}$ \\
\hline Cord blood & --- & $5.78 \pm 2.13$ & $10.22 \pm 1.43^{1}$ & --- & $19.46 \pm 4.39^{\mathrm{x}}$ \\
\hline
\end{tabular}

IFN - interferon, IL - interleukin, TNF - tumour necrosis factor. V1 - 28 to 32 weeks of gestation, V2 - 36 to 38 weeks of gestation, V3 - after delivery. Values are mean \pm SEM. ${ }^{*} p<0.05$ vs. non-pregnant women, One way ANOVA/ANOVA on Ranks. ${ }^{1} p<0.05$ vs. V1; One Way repeated measures ANOVA/One way repeated measures ANOVA on Ranks. ${ }^{2} p<0.05$ vs. V2; One Way repeated measures ANOVA/One way repeated measures ANOVA on Ranks. ${ }^{x} p<0.05$ vs. pregnant women without GDM; unpaired $t$-test or Mann-Whitney Rank Sum Test. 

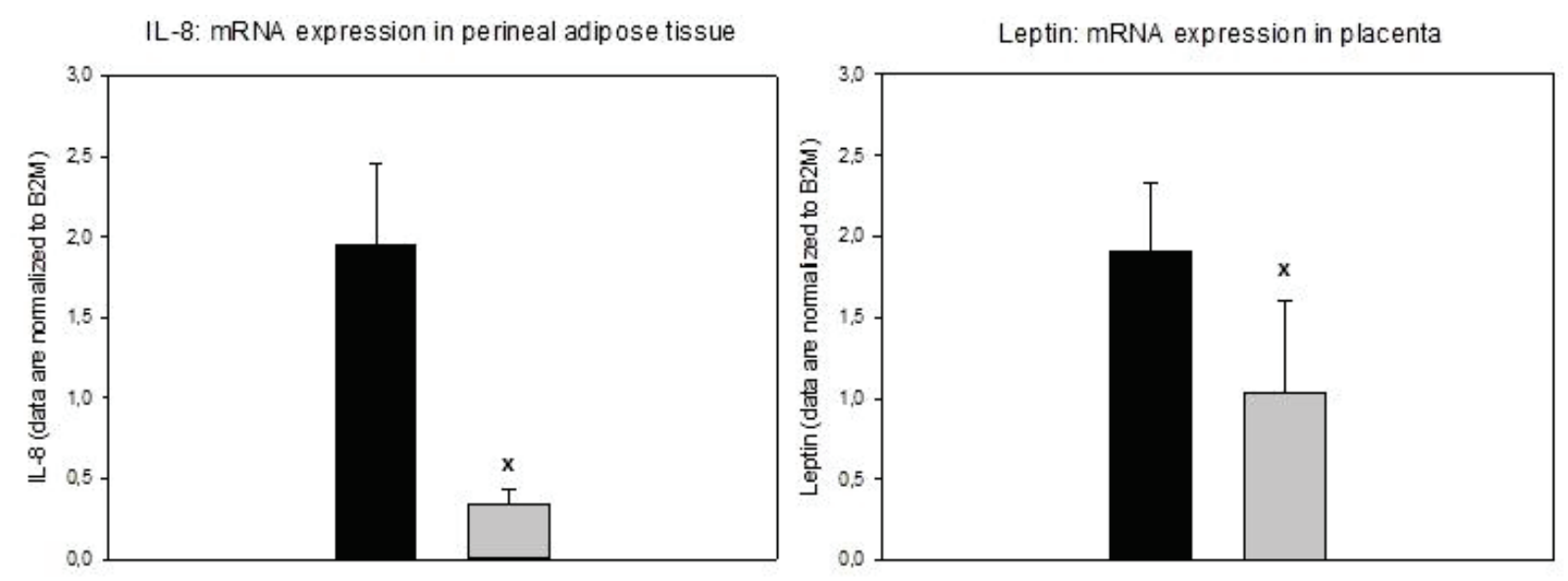

Fig. 2. The effect of GDM on mRNA expression IL-8 in perineal adipose tissue and placental mRNA expression of leptin. $P$ - pregnant women without GDM, GDM - pregnant women with GDM, IL - interleukin. Values are mean \pm SEM. ${ }^{\times} p<0.05$ vs. pregnant women without GDM; unpaired t-test or Mann-Whitney Rank Sum Test.

The relationship of fetuin A, fetuin B and FGF21 to other studied parameters

Plasma fetuin A positively correlated with uric acid $(\mathrm{R}=0.897, \mathrm{p}=0.025)$ and CRP levels $(\mathrm{R}=0.379$, $\mathrm{p}=0.032$ ) and was inversely related with creatinine $(\mathrm{R}=-0,372, \mathrm{p}=0.036)$ and total bilirubin $(\mathrm{R}=-0.396$, $\mathrm{p}=0.025)$. Fetuin A positively correlated with fetuin $B$ levels $(\mathrm{R}=0.497, \mathrm{p}=0.003)$, TNF- $\alpha$ mRNA expression in perineal adipose tissue $(\mathrm{R}=0.699, \mathrm{p}=0.035)$ and $\mathrm{IL}-6$ mRNA expression in placenta $(\mathrm{R}=0.468, \mathrm{p}=0.021)$.

Plasma fetuin B levels positively correlated with triglycerides $(\mathrm{R}=0.497, \mathrm{p}=0.013)$ and CRP levels $(\mathrm{R}=0.466, \mathrm{p}=0.007)$ and were inversely correlated with total bilirubin $(\mathrm{R}=-0.391, \mathrm{p}=0.027)$. Fetuin $\mathrm{B}$ positively correlated with fetuin A levels $(\mathrm{R}=0.497, \mathrm{p}=0.003)$.

Plasma FGF21 levels positively correlated with creatinine $(\mathrm{R}=0.410, \mathrm{p}=0.020)$, GGT $(\mathrm{R}=0.436, \mathrm{p}=0.023)$ and inversely correlated with ALP levels $(\mathrm{R}=-0.484$, $\mathrm{p}=0.041)$ and LDL cholesterol $(\mathrm{R}=-0.451, \mathrm{p}=0.027)$. FGF21 positively correlated with IFN- $\gamma$ mRNA expression in perineum adipose tissue $(\mathrm{R}=0.685$, $\mathrm{p}=0.025$ ) and negatively correlated with IL- 8 mRNA expression in placenta $(\mathrm{R}=-0.500, \mathrm{p}=0.013)$.

\section{Discussion}

Liver plays a central role in the regulation of glucose homeostasis as not only a major place of gluconeogenesis and glycogen storage but also as a source of numerous hormones commonly referred to as hepatokines (Abdul-Wahed et al. 2014). These hormones including fetuin A, fetuin B and FGF21 have all been connected with the regulation of glucose metabolism and energy homeostasis (Dostalova et al. 2009, Cheung and Deng 2014, Ix et al. 2006). In the present study, we aimed to determine the changes in fetuin A, fetuin B and FGF21 in women with physiological pregnancy and gestational diabetes mellitus and their possible interconnections with clinical features and measures of glucose metabolism and subclinical inflammation. We have demonstrated that fetuin $\mathrm{A}$ and fetuin $\mathrm{B}$ plasma levels are increased during pregnancy with only limited effect of the presence of GDM. In contrast, we found a different pattern of changes in FGF21 levels in healthy pregnant women and GDM patients.

Some of the previous studies demonstrated increased fetuin A levels in the second and third trimester of pregnancy in GDM patients as compared to healthy pregnant women (Kalabay et al. 2002) or decreased fetuin A levels in patients with preeclampsia (Molvarec et al. 2009). In contrast, other studies did not show any influence of GDM on serum fetuin A levels (Farhan et al. 2012). In our study, we found higher levels of fetuin $A$ during the 28 to 38 weeks of pregnancy in healthy pregnant women compared to non-pregnant women, while women with GDM had higher fetuin A levels only at 28 to 32 weeks of gestation. Delivery significantly decreased fetuin A levels only in healthy pregnant women while its change in GDM group did not reach statistical significance despite the similar trend. 
Importantly, fetuin A levels in 28 to 38 weeks of pregnancy did not differ between pregnant women without and with GDM in our study, which is in line with results of some studies (Farhan et al. 2012) but in disagreement with other studies (Iyidir et al. 2015). The differences between our data and other studies can be explained by varying levels of glucose control in GDM patients, which was optimal in our study but suboptimal in other studies.

Previous studies have shown a potential connection of fetuin A to insulin resistance. For example: studies on $d b / d b$ mice described NF- $\kappa \mathrm{B}$ mediated lipidinduced fetuin $\mathrm{A}$ expression in hepatocytes (Dasgupta et al. 2010) and the role of fetuin $A$ as an endogenous ligand of toll-like receptor 4 promoting lipid-induced insulin resistance ( $\mathrm{Pal}$ et al. 2012). Possibly, an association between fetuin $\mathrm{A}$ and toll-like receptor 4 could be one of the explanations for its positive correlation with mRNA expression of TNF- $\alpha$ in adipose tissue or IL-6 in placenta in our study given a potential fetuin A modifying actions on lipopolysaccharide and endotoxemia (Basu et al. 2011, Dziegielewska et al. 1998).

According to a recently published study (Kralisch et al. 2017), fetuin B levels during pregnancy were increased in women with GDM compared to non-diabetic pregnant women with a drop in concentrations after delivery. Here we found equally increased fetuin B levels during pregnancy in both healthy pregnant and GDM groups with a significant decrease after delivery. We failed to demonstrate a difference in concentrations of fetuin B between pregnant women with and without GDM. This finding could be explained by the fact that GDM group had a perfect glucose control with glycated hemoglobin levels comparable to healthy non-diabetic pregnant women. Observed positive correlation between plasma fetuin B levels and triglycerides are consistent with increased fetuin B concentrations previously described in obese patients with liver steatosis (Meex et al. 2015).

Although fetuin A production was found in both subcutaneous and visceral adipose tissue in animal studies (Perez-Sotelo et al. 2017) we were not able to detect fetuin A mRNA expression in perineal adipose tissue as well as in other adipose tissue depots and found only weak fetuin B mRNA expression in some of the fat samples. Our data thus suggest inter-species differences in fetuin $\mathrm{A}$ and $\mathrm{B}$ mRNA expression with human adipose tissue expressing no fetuin A and a very little, if any, fetuin B. It has been previously shown that both fetuin A and fetuin $\mathrm{B}$ are produced in human and animal placenta (Denecke et al. 2003). Our results confirm fetuin A mRNA expression in placenta with no differences between the groups. In contrast, mRNA expression of fetuin B could be detected only in some of the samples.

In our study, the presence of GDM was associated with higher levels of proinflammatory TNF- $\alpha$ levels and anti-inflammatory IL-10 levels in 28 to 32 weeks of gestation suggesting that similarly to type 2 diabetes mellitus women with GDM also suffer from subclinical inflammation which in our study could not be detected by differences in CRP levels (Leipold et al. 2005). Interestingly, we also found increased TNF- $\alpha$ levels in the cord blood of newborns of women with GDM which is in contrast to some of the previously published data (Mahmoud et al. 2005). Furthermore, in our study we also noted a positive correlation of fetuin B with CRP levels while no such relationship was detected for fetuin A. Interestingly, no association between fetuin A or B and circulating cytokines could be detected in our study. All in all, these results suggest that fetuins are not major players in the induction of subclinical inflammation in patients with GDM.

In contrast to fetuin $\mathrm{A}$ and fetuin $\mathrm{B}$, changes in FGF21 during pregnancy were less consistent with a high degree of individual variability especially among GDM subjects. On the other hand, similar variability in FGF21 was found in our previously published study focusing on the obese subjects undergoing laparoscopic sleeve gastrectomy (Haluzikova et al. 2013). Similarly to others (Stein et al. 2010), we failed to find increased FGF21 levels in patients with GDM as it was suggested by some studies (Megia et al. 2015, Wang et al. 2013). The effect of pregnancy on the FGF21 level seems to be more complex. In our study, FGF21 levels in healthy pregnant women were lower at 28 to 32 weeks of gestation compared to non-pregnant subjects and increased in 36 to 38 weeks of gestation while different pattern was seen in GDM patients. In contrast to another study (Dekker Nitert et al. 2014), we detected FGF21 mRNA expression in the placenta only in half of the samples regardless the diagnosis of GDM. Together with an increased FGF21 levels after delivery in GDM women, these findings suggest potential ambiguous effect of placental production on maternal levels along with a possible role of FGF21 in the etiopathogenesis of GDM (Li et al. 2015).

Although the results did not reach statistical 
significance, patients with GDM tended to have increased FGF21 in the early third trimester, soon after the manifestation of GDM. FGF21 is known to stimulate gluconeogenesis in the liver and induce lipolysis in white adipose tissue (Cheung and Deng 2014) along with increased insulin mRNA expression in pancreas and circulating insulin levels (Dostalova et al. 2009). Taken together elevated FGF21 levels are associated with decreased insulin sensitivity. The fact that increased concentration persisted after delivery suggests that elevation of FGF21 may not be just a transient consequence of GDM but rather an overall predisposition towards impaired glucose metabolism. Increased FGF21 levels after delivery may also represent a link between GDM and later disturbances in metabolism as similarly elevated FGF21 concentrations were also observed in obesity and type 2 diabetes mellitus (Dostalova et al. 2009, Mumtaz et al. 2015), hypertension, atherosclerosis and coronary artery disease (Cheung and Deng 2014). It can also explain the high recurrence rate of GDM in the subsequent pregnancy.

Our study has several limitations that could have partially affected its results. One of the limitations is a relatively small sample size which could have contributed to failure of some comparisons to reach statistical significance. Adipose tissue samples could only be obtained from women who either had the episiotomy or cesarean section performed. With respect to ethical aspects, we aimed to avoid any unnecessary trauma during the delivery. Also, the mode of delivery was unknown at the time of recruitment. This approach was intended to prevent subject's selection bias.

In summary, our study has shown that both fetuin A and fetuin B levels were significantly increased during pregnancy without major modulatory role of the presence of gestational diabetes mellitus. On the contrary, changes in FGF21 levels during pregnancy were less consistent and showed different pattern between healthy pregnant women and patients with gestational diabetes. All in all, fetuin A and B do not appear to be responsible for metabolic disturbances or differences in subclinical inflammation in patients with gestational diabetes mellitus. The possible role of FGF21 in these processes seems more likely. Further studies on a higher number of patients will be necessary to bring more definitive answers with respect to a complex role of these hepatokines in the regulation of glucose homeostasis and glucose metabolism during pregnancy.

\section{Conflict of Interest}

There is no conflict of interest.

\section{Acknowledgements}

Supported by AZV 15-27630A.

\section{References}

ABDUL-WAHED A, GAUTIER-STEIN A, CASTERAS S, SOTY M, ROUSSEL D, ROMESTAING C, GUILLOU H, TOURETTE J A, PLECHE N, ZITOUN C, GRI B, SARDELlA A, RAJAS F, MITHIEUX G: A link between hepatic glucose production and peripheral energy metabolism via hepatokines. Mol Metab 3: 531-543, 2014.

BADMAN MK, PISSIOS P, KENNEDY AR, KOUKOS G, FLIER JS, MARATOS-FLIER E: Hepatic fibroblast growth factor 21 is regulated by PPARalpha and is a key mediator of hepatic lipid metabolism in ketotic states. Cell Metab 5: 426-437, 2007.

BASU S, HAGHIAC M, SURACE P, CHALLIER JC, GUERRE-MILLO M, SINGH K, WATERS T, MINIUM J, PRESLEY L, CATALANO PM, HAUGUEL-DE MOUZON S: Pregravid obesity associates with increased maternal endotoxemia and metabolic inflammation. Obesity (Silver Spring) 19: 476-482, 2011.

CHATTERJEE P, SEAL S, MUKHERJEE S, KUNDU R, MUKHERJEE S, RAY S, MUKHOPADHYAY S, MAJUMDAR SS, BHATTACHARYA S: Adipocyte fetuin-A contributes to macrophage migration into adipose tissue and polarization of macrophages. J Biol Chem 288: 28324-28330, 2013.

CHEUNG BM, DENG HB: Fibroblast growth factor 21: a promising therapeutic target in obesity-related diseases. Expert Rev Cardiovasc Ther 12: 659-666, 2014.

DASGUPTA S, BHATTACHARYA S, BISWAS A, MAJUMDAR SS, MUKHOPADHYAY S, RAY S, BHATTACHARYA S: NF-kappaB mediates lipid-induced fetuin-A expression in hepatocytes that impairs adipocyte function effecting insulin resistance. Biochem $J$ 429: 451-462, 2010. 
DEKKER NITERT M, BARRETT HL, KUBALA MH, SCHOLZ ROMERO K, DENNY KJ, WOODRUFF TM, MCINTYRE HD, CALLAWAY LK: Increased placental expression of fibroblast growth factor 21 in gestational diabetes mellitus. J Clin Endocrinol Metab 99: E591-E598, 2014.

DENECKE B, GRABER S, SCHAFER C, HEISS A, WOLTJE M, JAHNEN-DECHENT W: Tissue distribution and activity testing suggest a similar but not identical function of fetuin-B and fetuin-A. Biochem J 376: 135-145, 2003.

DOSTALOVA I, HALUZIKOVA D, HALUZIK M: Fibroblast growth factor 21: a novel metabolic regulator with potential therapeutic properties in obesity/type 2 diabetes mellitus. Physiol Res 58: 1-7, 2009.

DZIEGIELEWSKA KM, ANDERSEN NA, SAUNDERS NR: Modification of macrophage response to lipopolysaccharide by fetuin. Immunol Lett 60: 31-35, 1998.

ELNOUR AA, EL MUGAMMAR IT, JABER T, REVEL T, MCELNAY JC: Pharmaceutical care of patients with gestational diabetes mellitus. $J$ Eval Clin Pract 14: 131-140, 2008.

FARHAN S, HANDISURYAA, TODORIC J, TURA A, PACINI G, WAGNER O, KLEIN K, JARAI R, HUBER K, KAUTZKY-WILLER A: Fetuin-A characteristics during and after pregnancy: result from a case control pilot study. Int J Endocrinol 2012: 896736, 2012.

FON TACER K, BOOKOUT AL, DING X, KUROSU H, JOHN GB, WANG L, GOETZ R, MOHAMMADI M, KURO-O M, MANGELSDORF DJ, KLIEWER SA: Research resource: comprehensive expression atlas of the fibroblast growth factor system in adult mouse. Mol Endocrinol 24: 2050-2064, 2010.

HALUZIKOVA D, LACINOVA Z, KAVALKOVA P, DRAPALOVA J, KRIZOVA J, BARTLOVA M, MRAZ M, PETR T, VITEK L, KASALICKY M, HALUZIK M: Laparoscopic sleeve gastrectomy differentially affects serum concentrations of FGF-19 and FGF-21 in morbidly obese subjects. Obesity (Silver Spring) 21: 1335-1342, 2013.

HENNIGE AM, STAIGER H, WICKE C, MACHICAO F, FRITSCHE A, HARING HU, STEFAN N: Fetuin-A induces cytokine expression and suppresses adiponectin production. PLoS One 3: e1765, 2008.

IX JH, SHLIPAK MG, BRANDENBURG VM, ALI S, KETTELER M, WHOOLEY MA: Association between human fetuin-A and the metabolic syndrome: data from the Heart and Soul Study. Circulation 113: 1760-1767, 2006.

IYIDIR OT, DEGERTEKIN CK, YILMAZ BA, ALTINOVA AE, TORUNER FB, BOZKURT N, AYVAZ G, AKTURK M: Serum levels of fetuin A are increased in women with gestational diabetes mellitus. Arch Gynecol Obstet 291: 933-937, 2015.

JIALAL I, DEVARAJ S, BETTAIEB A, HAJ F, ADAMS-HUET B: Increased adipose tissue secretion of fetuin-A, lipopolysaccharide-binding protein and high-mobility group box protein 1 in metabolic syndrome. Atherosclerosis 241: 130-137, 2015.

KALABAY L, CSEH K, PAJOR A, BARANYI E, CSAKANY GM, MELCZER Z, SPEER G, KOVACS M, SILLER G, KARADI I, WINKLER G: Correlation of maternal serum fetuin/alpha2-HS-glycoprotein concentration with maternal insulin resistance and anthropometric parameters of neonates in normal pregnancy and gestational diabetes. Eur J Endocrinol 147: 243-248, 2002.

KHARITONENKOV A, SHIYANOVA TL, KOESTER A, FORD AM, MICANOVIC R, GALBREATH EJ, SANDUSKY GE, HAMMOND LJ, MOYERS JS, OWENS RA, GROMADA J, BROZINICK JT, HAWKINS ED, WROBLEWSKI VJ, LI DS, MEHRBOD F, JASKUNAS SR, SHANAFELT AB: FGF-21 as a novel metabolic regulator. $J$ Clin Invest 115: 1627-1635, 2005.

KRALISCH S, HOFFMANN A, LOSSNER U, KRATZSCH J, BLUHER M, STUMVOLL M, FASSHAUER M, EBERT T: Regulation of the novel adipokines/hepatokines fetuin A and fetuin B in gestational diabetes mellitus. Metabolism 68: 88-94, 2017.

LEIPOLD H, WORDA C, GRUBER CJ, PRIKOSZOVICH T, WAGNER O, KAUTZKY-WILLER A: Gestational diabetes mellitus is associated with increased C-reactive protein concentrations in the third but not second trimester. Eur J Clin Invest 35: 752-757, 2005.

LI SM, WANG WF, ZHOU LH, MA L, AN Y, XU WJ, LI TH, YU YH, LI DS, LIU Y: Fibroblast growth factor 21 expressions in white blood cells and sera of patients with gestational diabetes mellitus during gestation and postpartum. Endocrine 48: 519-527, 2015. 
MAHMOUD F, ABUL H, OMU A, HAINES D: Lymphocyte sub-populations in gestational diabetes. Am J Reprod Immunol 53: 21-29, 2005.

MEEX RC, HOY AJ, MORRIS A, BROWN RD, LO JC, BURKE M, GOODE RJ, KINGWELL BA, KRAAKMAN MJ, FEBBRAIO MA, GREVE JW, RENSEN SS, MOLLOY MP, LANCASTER GI, BRUCE CR, WATT MJ: Fetuin B is a secreted hepatocyte factor linking steatosis to impaired glucose metabolism. Cell Metab 22: 1078-1089, 2015.

MEGIA A, GIL-LLUIS P, NAF S, CEPERUELO-MALLAFRE V, GONZALEZ-CLEMENTE JM, LLAURADO G, NUNEZ-ROA C, ROCHE K, BALLESTEROS M, YANEZ R E, FERNANDEZ-VELEDO S, VENDRELL J: Cord blood FGF21 in gestational diabetes and its relationship with postnatal growth. Acta Diabetol 52: 693-700, 2015.

MOLVAREC A, KALABAY L, DERZSY Z, SZARKA A, HALMOS A, STENCZER B, ARNAUD P, KARADI I, PROHASZKA Z, RIGO J JR: Preeclampsia is associated with decreased serum alpha(2)-HS glycoprotein (fetuin-A) concentration. Hypertens Res 32: 665-669, 2009.

MRAZ M, BARTLOVA M, LACINOVA Z, MICHALSKY D, KASALICKY M, HALUZIKOVA D, MATOULEK M, DOSTALOVA I, HUMENANSKA V, HALUZIK M: Serum concentrations and tissue expression of a novel endocrine regulator fibroblast growth factor-21 in patients with type 2 diabetes and obesity. Clin Endocrinol (Oxf) 71: 369-375, 2009.

MUMTAZ S, ALSAIF S, WRAY S, NOBLE K: Inhibitory effect of visfatin and leptin on human and rat myometrial contractility. Life Sci 125: 57-62, 2015.

OGAWA Y, KUROSU H, YAMAMOTO M, NANDI A, ROSENBLATT KP, GOETZ R, ELISEENKOVA AV, MOHAMMADI M, KURO-O M: BetaKlotho is required for metabolic activity of fibroblast growth factor 21 . Proc Natl Acad Sci U S A 104: 7432-7437, 2007.

PAL D, DASGUPTA S, KUNDU R, MAITRA S, DAS G, MUKHOPADHYAY S, RAY S, MAJUMDAR SS, BHATTACHARYA S: Fetuin-A acts as an endogenous ligand of TLR4 to promote lipid-induced insulin resistance. Nat Med 18: 1279-1285, 2012.

PEREZ-SOTELO D, ROCA-RIVADA A, LARROSA-GARCIA M, CASTELAO C, BAAMONDE I, BALTAR J, CRUJEIRAS AB, SEOANE LM, CASANUEVA FF, PARDO M: Visceral and subcutaneous adipose tissue express and secrete functional alpha2hsglycoprotein (fetuin a) especially in obesity. Endocrine 55: 435-446, 2017.

SESHIAH V, DAS AK, BALAJI V, JOSHI SR, PARIKH MN, GUPTA S: Gestational diabetes mellitus - guidelines. J Assoc Physicians India 54: 622-628, 2006.

SPOLCOVA A, HOLUBOVA M, MIKULASKOVA B, NAGELOVA V, STOFKOVA A, LACINOVA Z, JURKOVICOVA J, HALUZIK M: Changes in FGF21 serum concentrations and liver mRNA expression in an experimental model of complete lipodystrophy and insulin-resistant diabetes. Physiol Res 63: 483-490, 2014.

SRINIVAS PR, WAGNER AS, REDDY LV, DEUTSCH DD, LEON MA, GOUSTIN AS, GRUNBERGER G: Serum alpha 2-HS-glycoprotein is an inhibitor of the human insulin receptor at the tyrosine kinase level. $\mathrm{Mol}$ Endocrinol 7: 1445-1455, 1993.

STEFAN N, HENNIGE AM, STAIGER H, MACHANN J, SCHICK F, KROBER SM, MACHICAO F, FRITSCHE A, HARING HU: Alpha2-Heremans-Schmid glycoprotein/fetuin-A is associated with insulin resistance and fat accumulation in the liver in humans. Diabetes Care 29: 853-857, 2006.

STEFAN N, FRITSCHE A, WEIKERT C, BOEING H, JOOST H G, HARING H U, SCHULZE M B: Plasma fetuin-A levels and the risk of type 2 diabetes. Diabetes 57: 2762-2767, 2008.

STEIN S, STEPAN H, KRATZSCH J, VERLOHREN M, VERLOHREN HJ, DRYNDA K, LOSSNER U, BLUHER M, STUMVOLL M, FASSHAUER M: Serum fibroblast growth factor 21 levels in gestational diabetes mellitus in relation to insulin resistance and dyslipidemia. Metabolism 59: 33-37, 2010.

SUN Q, CORNELIS MC, MANSON JE, HU FB: Plasma levels of fetuin-A and hepatic enzymes and risk of type 2 diabetes in women in the U.S. Diabetes 62: 49-55, 2013.

TELEJKO B, KUZMICKI M, ZONENBERG A, SZAMATOWICZ J, WAWRUSIEWICZ-KURYLONEK N, NIKOLAJUK A, KRETOWSKI A, GORSKA M: Visfatin in gestational diabetes: serum level and mRNA expression in fat and placental tissue. Diabetes Res Clin Pract 84: 68-75, 2009. 
VEJRAZKOVA D, VANKOVA M, LUKASOVA P, VCELAK J, CIRMANOVA V, HALUZIK M, BENDLOVA B: Specific metabolic characteristics of women with former gestational diabetes: the importance of adipose tissue. Physiol Res 66 (Suppl 3): S349-S356, 2017.

WANG D, ZHU W, LI J, AN C, WANG Z: Serum concentrations of fibroblast growth factors 19 and 21 in women with gestational diabetes mellitus: association with insulin resistance, adiponectin, and polycystic ovary syndrome history. PLoS One 8: e81190, 2013. 